\title{
KEBIJAKAN SEKOLAH ADIWIYATA SEBAGAI PENERAPAN PENDIDIKAN KARAKTER DI SMP NEGERI 2 DAYUN KABUPATEN SIAK
}

\author{
Er Azmawaty AR 1) \\ Sumarno ${ }^{2)}$ \\ Miharty ${ }^{3)}$
}

${ }^{1)}$ SMP Negeri 2 Dayun

${ }^{2)}$ Lecturer of Education Management Study Programme PPs University of Riau

3) Lecturer of Education Management Study Programme PPs University of Riau

\section{ABSTRACT}

This study aims (1). To analyze the implementation of adiwiyata school policies in SMP Negeri 2 Dayun. (2). To analyze the success of character education through the adiwiyata school policy at SMP Negeri 2 Dayun. The research method uses qualitative. The results of the study are Adiwiyata School Policy as the Application of Character Education in SMP Negeri 2 Dayun, Siak Regency, in fact it can run well as intended because it is carried out through the stages of character education development that has been launched by the Ministry of National Education (2010), namely through the knowledge stage, the implementation stage, and habituation stage (habituation). In this case the school has made improvements to the vision of the mission of the environmentcultured school, integrated environmental education with classroom learning, and formed a participatory-based work program so that it becomes a habit for students. Character values developed by SMP Negeri 2 Dayun through the Adiwiyata school policy on basically is the success of the stages of character education development carried out by the school, namely through the stages of knowledge (knowing), implementation (acting), and habits (habits). In this case the school carries out the implementation phase by empowering the Adiwiyata program as a basis in forming character values which are then carried out by the school consistently and continuously so that it can train students to get used to doing moral acts (moral acting).

Keywords: Adiwiyata; School Policy; Character Education 


\begin{abstract}
ABSTRAK
Penelitian ini bertujuan (1). Untuk menganalisis Pelaksanaan kebijakan sekolah adiwiyata di SMP Negeri 2 Dayun. (2). Untuk menganalisis keberhasilan pendidikan karakter melalui kebijakan sekolah adiwiyata di SMP Negeri 2 Dayun. Metode Penelitian menggunakan kualitatif. Hasil Penelitian adalah Kebijakan Sekolah Adiwiyata Sebagai Penerapan Pendidikan Karakter Di SMP Negeri 2 Dayun Kabupaten Siak sesungguhnya dapat berjalan dengan baik sesuai tujuan karena dilakukan melalui tahap-tahap pengembangan pendidikan karakter yang telah dicanangkan kementerian pendidikan nasional (2010), yaitu melalui tahap pengetahuan, tahap pelaksanaan, dan tahap habituasi (pembiasaan). Dalam hal ini sekolah telah melakukan penyempurnaan visi misi sekolah berbudaya lingkungan, mengintegrasikan pendidikan lingkungan hidup dengan pembelajaran dikelas, dan membentuk program kerja berbasis partisipatif sehingga menjadi kebiasaan bagi peserta didik.Nilai-nilai karakter yang dikembangkan oleh SMP Negeri 2 Dayun melalui kebijakan sekolah Adiwiyata pada dasarnya merupakan keberhasilan dari tahap-tahap pengembangan pendidikan karakter yang dilakukan oleh sekolah, yaitu melalui tahap pengetahuan (knowing), pelaksanaan (acting), dan kebiasaan (habit). Dalam hal ini sekolah melakukan tahap pelaksanaan dengan memberdayakan program Adiwiyata sebagai basis dalam membentuk nilai karakter yang kemudian dilakukan sekolah secara konsisten dan berkesinambungan sehingga dapat melatih peserta didik untuk terbiasa dalam melakukan perbuatan moral (moral acting).
\end{abstract}

Kata Kunci : Kebijakan Sekolah; Adiwiyata; Pendidikan Karakter

\section{PENDAHULUAN}

Gambaran situasi masyarakat Indonesia saat ini sangat memprihatikan. Generasi muda semakin rusak ditandai dengan semakin merebaknya khasus amoralitas dan kenakalan remaja yang dilakukan dalam berbagai bentuk seperti : komplotan yang dilakukan para pelajar di jalan raya, tawuran antar pelajar, pesta minuman keras dan penggunaan narkoba oleh mereka, bahkan yang lebih memperhatinkan amoralitas tersebut sudah di temukan pada anak-anak.

Akar dari semua tindakan jahat dan buruk, tindakan kejahatan terletak hilangnya karakter. Menurut Ratna dalam Dharma (2011:4) Pendidikan Karakter merupakan sebuah usaha untuk mendidik anak-anak agar dapat mengambil keputusan dengan bijak dan mempraktekkan dalam kehidupan sehari-hari, sehingga mereka dapat memberikan kontribusi yang positif kepada lingkungan. Karakter bangsa Indonesia adalah karakter yang dimiliki warga Negara Indonesia berdasarkan tindakan-tindakan yang dinilai sebagai suatu kebajikan berdasarkan nilai yang berlaku dimasyarakat dan bangsa Indonesia.

Dengan karakter yang kuat menjadi sandangan fundamental yang memberikan kemampuan kepada populasi manusia untuk hidup bersama dalam kedamaian serta membentuk dunia yang dipenuhi dengan kebaikan dan kebajikan, yang bebas dari kekerasan dan tindakan-tindakan yang tidak bermoral. mencermati hal itu perlu mengingak kembali rumusan pendidikan di Negara ini.

Dari beberapa jenis nilai-nilai karakter di atas, terdapat nilai karakter 
yang sangat dibutuhkan dan tidak mungkin ditunda-tunda lagi, mengingat kondisi ketidak nyamanan lingkungan Indonesia sekarang ini. Negara ini dahulunya dikenal sebagai sebuah negeri kepulauan yang membentang disepanjang garis katulistiwa yang mempunyai tanah subur, sehingga membuat para penghuninya merasa tenang, nyaman, dan makmur. namun seiring dengan berkembangnya peradaban umat manusia, Indonesia sudah tidak lagi nyaman untuk di huni. tanahnya menjadi gersang dan tandus, akibatnya bibit unggul pun gagal tumbuh di negeri ini. hal ini dengan terjadinya bencana seperti banjir bandang, tanah longsor, sunami dan kekeringan yang seolah-olah sudah menjadi fenomena tahunan yang terus dan terus terjadi. sementara itu pembakaran hutan, pemburuan satwa liar, bahkan penebangan liar nyaris tidak pernah luput dari agenda para perusak lingkungan.

Sebenarnya pemerintah telah berupaya dalam menyikapi masalah terkait lingkungan dengan upaya pencegahan sejak dini. Hal ini ditunjukan dengan adanya kesepakatan bersama yang telah dibangun oleh Menteri Lingkungan Hidup dan Menteri Pendidikan Nasional tentang ", Pendidikan Lingkungan Hidup" yang diikuti dengan langkah pemberian pendidikan lingkungan hidup bagi lembaga-lembaga pendidikan. Namun kenyatanya upaya pemerintah tersebut tidak mendapat dukungan dari para penyelenggaraan dan pelaksanaan pendidikan. Kebersamaan warga sekolah sangat diperlukan dalam mewujudkan lembaga pendidikan yang peduli lingkungan. Peserta didik yang membuang sampah sembarangan menjadi tidak tumbuh kesadaran karena sebagian warga sekolah lainya dibiarkan dan tidak ditegur. Berkaitan dengan kurang dipahaminya tujuan sekolah peduli lingkungan meskipun telah menerima sosialisasi.

Peraturan yang melandasi kebijakan sekolah peduli dan berbudaya lingkungan meliputi Memorandum bersama Mendiknas No 0142/U/1996 dan No. Kep 89/MenLH/5/1996, Kesepakatan Bersama dengan Depdiknas KEP 7/MenLH/06/2005 dan No. 05/VI/KB/2005, UU No 20 Tahun 2003, UU RI No. 32 Tahun 2009 pada tingkat nasional kebijakan sekolah peduli dan berbudaya lingkungan. Tentang penetapan nama sekolah imbas yang mendapat pembinaan oleh sekolah Kebijakan dan Pengembangan Pendidikan Volume 2, Nomor 1, Januari 2014; 82-88 ISSN: 2337-7623; EISSN: 2337-7615 85 Adiwiyata tingkat nasional.

Untuk mewujudkan sekolah yang peduli dan berbudaya lingkungan maka diperlukan model pengelolaan sekolah yang mendukung dilaksanakannya pendidikan lingkungan hidup oleh semua warga sekolah sesuai dengan prinsip-prinsip dasar sekolah Adiwiyata yakni partisipatif dan berkelanjutan. Berdasarkan pendapat informan bahwa kebijakan lingkungan hidup di sekolah sudah dituangkan dalam Kepala Sekolah Nomor 800/117-SMP.04/2013 dan terintegrasi dalam masing-masing mata pelajaran. Begitu juga dengan visi dan misi yang sudah disesuaikan kearah peduli lingkungan yang hal ini sesuai dengan pendapat informan yang diperkuat pula oleh pendapat informan lainnya. Visi dan misi tersebut juga terpampang di dinding agar dapat diketahui oleh semua warga sekolah.Untuk itu, Pemerintah berupaya merangsang minat warga sekolah untuk bersungguh-sungguh menumbuhkan semangat peduli lingkunagan, dengan memberikan penghargaan sekolah 
adiwiyata dan di rangking berdasarkan kreteria- kreteria yang telah ditetapkan.

SMP Negeri 2 Dayun adalah salah satu sekolah Adiwiyata di Kabupaten Siak. Sekolah ini berada di wilayah Kecamatan Dayun yaitu sekitar $21 \mathrm{Km}$ dari kota Kabupaten Siak. SMP Negeri 2 Dayun didirikan pada tahun 2001/2002 di areal tanah milik Pemda seluas $\quad 15.000 \mathrm{M}^{2}$. Pada perkembangannya sekolah ini terakreditasi dengan nilai A (94) pada tahun 2016. SMP Negeri 2 Dayun memiliki 16 ruang rombel yang terdiri dari 6 ruang rombel kelas 7, 6 ruang rombel kelas 8 dan 4 ruang rombel kelas 9, dengan jumlah siswa 433 siswa pada tahun 2016 / 2017. Data jumlah guru pada tahun 2017 adalah sebanyak 28 orang, dengan rincian guru PNS sebanyak 12 orang dan guru tidak tetap/ guru bantu sebanyak 16 orang. Tenaga administrasi (TU) di SMP Negeri 2 dayun sebanyak 7 orang dan penjaga sekolah 2 orang.

SMP Negeri 2 Dayun mulai mengimplementasikan kebijakan adiwiyata pada tahun 2013 dan mendapat prediket sekolah adiwiyata tingkat Kabupaten dengan Surat Keputusan Bupati Siak No. 253 / HK / KPTS / 2014 tentang nama-nama sekolah Adiwiyata berprestari tingkat SD, SMP, SMA/SMK pada tahun 2014. Kemudian secara berturut-turut pada tahun 2015 SMP Negeri 2 Dayun mendapat penghargaan Sekolah Adiwiyata Propinsi Riau dengan pigam penghargan yang diberikan oleh Guburnur Riau pada bulan Agustus 2015 dan pada tahun itu juga berhasil menyandang Sekolah Adiwiyata Tingkat Nasional dengan Surat Keputusan Menteri Lingkungan Hidup Dan Kehutanan Repulik Indonesia No. 610/MENLHK-BP2SDM/2015 tentang penerimaan penghargaan Sekolah Adiwiyata Nasional tahun 2015.
Keberhasilan ini tidak lepas dari peran serta segenap civitas sekolah, Komite Sekolah dan Wali Murid SMP Negeri 2 Dayun.

Penghargaan ini menunjukan bahwa SMP Negeri 2 Dayun telah berhasil menjadi sekolah yang berwawasan lingkungan. Dalam artian bahwa SMP Negeri 2 Dayun telah memenuhi prinsip-prinsip dasar adiwiyata, dan melaksanakan 4 komponen program sebagai sekolah adiwiyata, yang mana pelaksanaannya tidak lepas dari peran tim sekolah yang terdiri dari beberapa unsur diantaranya wakil kepala sekolah, kepala urusan, guru, wali kelas, siswa, komite sekolah, pengawas sekolah dan wali murid (Komite Kelas). Pelaksanaan sekolah Adiwiyata SMP Negeri 2 Dayun antara lain sebagai berikut : a). Mengkaji kondisi lingkungan hidup sekolah, kebijakan sekolah, kurikulum sekolah, kegiatan sekolah dan sarana prasarana. b). Membuat rencana kerja dan mengalokasikan anggaran sekolah berdasarkan hasil kajian dan disesuaikan dengan komponen standar, dan kebijakan adiwiyata, c). Melaksanakan rencana kerja sekolah, d). Melakukan Pemantauan dan evaluasi, e). Menyampaikan laporan kepada kepala sekolah tembusan Badan Lingkungan Hidup Kabupaten. Sesuai dengan visinya yaitu dengan Pembelajaran Efektif, Inovatif, Mewujudkan Sekolah Yang Berkwalitas, Beriman, Berakhlak Mulia, Berbudaya dan Peduli Lingkungan sedangkan misi sekolah SMP Negeri 2 Dayun adalah a). Mengoptimalkan serta mengefktifkan waktu belajar b). Mendorong warga sekolah untuk melakukan berbagai inovasi. c). Membantu siswa untuk mengenali dan mengembangkan potensi diri. d). Menanamkan semangat keunggulan pada warga sekolah. e). Menumbuhkan 
sikap memelihara dan mencegah pencemaran lingkungan. f). Menciptakan generasi yang peduli lingkungan sehingga dapat mencegah kerusakan lingkungan. g). membudayakan hidup bersih, sehat, cinta lingkungan sekolah dan masyarakat. h). Mendorong siswa untuk berprestasi dibidang akademis dan non akademis. i). Menumbuh kembangkan penghayatan dan pengamalan agama disekolah. j). Menumbuhkan kecintaan warga sekolah terhadap kesenian daerah

Oleh karena itu penulis akan melakukan penelitian kualitatif untuk menganalisis lebih mendalam faktorfaktor yang mempengaruhi pendidik karakter. Dengan Judul Penelitian: Kebijakan Sekolah Adiwiyata Sebagai Penerapan Pendidikan Karakter Di SMP Negeri 2 Dayun Kabupaten Siak.

\section{Fokus dan Subfokus Peneltian}

Merujuk pada latar belakang, maka yang menjadi fokus pada penelitian ini adalah Kebijakan Sekolah Adiwiyata Sebagai Penerapan Pendidikan Karakter Di SMP Negeri 2 Dayun Kabupaten Siak.Beberapa aspek yang diamati sebagai subfokus dalam penelitian ini adalah sebagai berikut:

a. Pelaksanaan kebijakan sekolah adiwiyata di SMP Negeri 2 Dayun.

b. Keberhasilan pendidikan karakter melalui kebijakan sekolah adiwiyata di SMP Negeri 2 Dayun.

\section{KERANGKA TEORITIS}

Menurut Sumarno (Jurnal Pekbis, 2011) sekolah perlu menerapkan Manajemen Pengetahuan sebagai pelengkap dan Pengintegrasian dari Manajemen Berbasis Sekolah yang sekarang ini masih dalam masingmasing Manajemen komponen sekolah, karena melalui Manajemen Pengetahuan akan tercipta organisasi pembelajar yang memungkinkan setiap individu yang akan menjadi berkembang sehingga dapat membelajarkan muridsecara optimal dan akhirnya Mutu sekolah akan meningkat.

Menurut Nugroho (2008 : 53) kebijakan adalah suatu program yang memproyeksikan dengan tujuan-tujuan tertentu, nilai-nilai tertentu dan praktek-praktek tertentu. Sedangkan Menurut Nugroho (2008:36) kebijakan pendidikan merupakan kunci bagi keunggulan, bahkan eksistensi bagi negara-negara dalam persaingan global, sehingga kebijakan pendidikan perlu mendapatkan prioritas utama dalam era globalisasi.

Kebijakan adalah sebagai suatau rangkaian kegiatan yang meliputi perumusan, analisis, implementasi, monitoring/pemantauan serta evalusi seputar masalah pendidikan yang diterapkan dalam menjawab tatantangan pendidikan dan diberlakukan secara periodik.

Menurut Hasbullah (2015: 50) berikut ini kriteria yang dapat digunakan dalam menentukan salah satu di antara berbagai kebijakan:

1. Rumusan kebijakan pendidikan tidak mendektekan keputusan spesifik atau hanya menciptakan lingkungan tertentu

2. Rumusan kebijakan pendidikan dapat dipergunakan menghadapi masalah atau situasi yang timbul secara berulang, artinya baik waktu, tenaga, biaya yang banyak dihabiskan tidak hanya sekedar dipergunakan memecahkan suatu maslah atau situasi tertentu saja, tapi diupayakan lebih menyeluruh dan holistik.

\section{ADIWIYATA}

Menurut KLH RI ( 2012: 20) Adiwiyata sebagai tempat yang baik dan ideal dimana dapat diperoleh 
segala ilmu pengetahuan dan berbagai norma serta etika yang dapat menjadi dasar manusia menuju terciptanya kesejahteraan hidup kita dan menuju kepada cita-cita pembangunan berkelanjutan.

Sekolah adiwiyata adalah sekolah yang peduli terhadap lingkungan dan menumbuhkan budaya lingkungan hidup dalam setiap kegiatan dan pembelajaran di sekolah

\section{Indikator Dan Kriteria Sekolah Adiwiyata}

Untuk mewujudkan sekolah Adiwiyata ditetapkan indikator dan kriteria yaitu :

a. Kebijakan Berwawasan Lingkungan
1. Kurikulu
Tingkat
Satuan
Pendidikan
(KTSP)
memuat
upaya perlindungan dan pengelolaan lingkungan hidup.

2. RKAS memuat program dalam upaya perlindungan dan pengelolaan lingkungan hidup.

b. Pelaksanaan Kurikulum Berbasis Lingkungan, memiliki standar :

1. Tenaga pendidik memiliki kompetensi dalam mengembangkan kegiatan pembelajaran lingkungan hidup.

2. Peserta didik melakukan kegiatan pembelajaran tentang perlindungan dan pengelolaan lingkungan hidup.

c. Kegiatan Lingkungan Berbasis Partisipasif Memiliki Standar :

1. Melaksanakan kegiatan perlindungan dan pengelolaan lingkungan hidup yang terencana bagi warga sekolah.

2. Menjalin kemitraan dalam rangka perlindungan dan pengelolaan lingkungan hidup dengan berbagai pihak (masyarakat, pemerintah, swasta, media,sekolah lain). d. Pengelolaan Sarana Pendukung

Ramah Lingkung memiliki Standar :

1. Ketersediaan sarana prasarana pendukung yang ramah lingkungan.

2. Peningkatan kualitas pengelolaan sarana dan prasarana yang ramah lingkungan di sekolah

\section{Pendidikan Karakter}

Wynne dalam Mulyasa (2005: 3) mengemukakan bahwa pendidikan karakter berasal dari Bahasa yunani yang berarti " to mark'"(menandai) dan memfokuskan pada bagimana menerapkan nilai-nilai kebaikan dalam tidakan nyata atau prilaku seharihari.oleh sebab itu,seseorang yang berperilaku titak jujur, curang, kejam dan rakus dikatakan sebagai orang yang memiliki karakter jelek, sedangkan yang berperilaku baik, jujur, dan suka menolong dikatakan sebagai orang yang memilikikarakter baik/mulia.

Pendidikan karakter adalah pendidikan yang menanamkan dan mengembangkan karakter-karakter luhur kepada anak, sehingga mereka memiliki kepribadian, akhlak mulia, dan budi pekerti sehingga karakter terbentuk dan menjadi ciri khas pada anak.

\section{Indikator Pendidikan Karakter}

Menurut Mulyasa (2005:11) Pendidikan Karakter Harus Mengacu Pada Indicator Keberhasilan yaitu sebagai berikut :

a. Mendeskripsikan gejala alam dan social

b. Memanfaatkan lingkungan secara bertanggung jawab

c. Menerapkan nilai-nilai kebersamaan dalam kehidupan masyarakat, bangsa, dan bernegara demi terhujudnya persatuan dalam Negara Kesatuan Republik Indonesia. 
d. Menghargai karya seni dan budaya nasional

e. Menghargai tugas pekerjaan dan memiliki kemampuan untuk berkarya

f. Menerapkan hidup bersih, sehat, bugar, aman, dan manfaatkan waktu luang dengan baik

g. Merawat diri dan lingkungan sekolah.

\section{METODOLOGI PENELITIAN}

Penelitian ini dilakukan di SMP Negeri 2 Dayun Kabupaten Siak. Waktu Penelitian dilaksanakan sejak bulan Pebruari 2018 sampai dengan Juni 2018 ,informan penelitian yaitu orangorang yang dianggap mengetahui masalah yang sedang diteliti diantaranya adalah wakil Kurikulum, wakil Kesiswaan, Ka. TU, Guru IPA, dan Ketua OSIS. Teknik pengumpulan data dilakukan dengan cara observasi langsung ke lapangan dan wawancara mendalam ( in-depth interview) dengan informan serta pengumpulan bukti fisik dalam dokumentasi.

Teknik Menjamin Keabsahan Data Teknik keterpercayaan maksudnya seberapa lama peneliti berada dan terlibat pada latar penelitian. Keteralihan ini dapat memberikan gambaran yang jelas mengenai latar atau situasi bagaimana agar temuan penelitian ini dapat diaplikasikan atau dipergunakan pada konteks lain. Peneliti mengusahakan konsistensi dalam keseluruhan proses penelitian agar dapat memenuhi syarat yang berlaku, Untuk keperluan kepastian, peneliti memperhatikan hasil catatan dan rekaman lapangan dan koherensi internal dalam penyajian interpretasi dan kesimpulan-kesimpulan hasil penelitian, Teknik dianalisis data dengan menggunakan langkah-langkah yaitu: (1) mereduksi data, (2) menyajikan data, (3) menyimpulkan dan melakukan verifikasi.

\section{HASIL PENELITIAN DAN PEMBAHASAN \\ Pelaksanaan Kebijakan Sekolah Adiwiyata}

Dari hasil wawancara dapat diketahui bahwa pelaksanaan kebijakan sekolah Adiwiyata di SMP Negeri 2 Dayun Kabupaten Siak Sebagai Penerapan Pendidikan Karakter. Melalui pelaksanaan perencanaan, pelaksanaan pengorganisasian, pelaksanaan pengarahan, sampai kepada pelaksanaan pengawasan yang dilakukan oleh kepala sekolah, pada dasarnya perencanaan merupakan suatu proses yang berhubungan dengan penilaian

Pertama adalah kebijakan sekolah Adiwiyata, yaitu visi, misi, tujuan dan kurikulum sekolah mencantumkan perlindungan dan pengelolaan lingkungan hidup. Visi, misi dan tujuan sekolah yang tertuang dalam kurikulum sekolah sudah memuat kebijakan perlindungan dan pengelolaan lingkungan hidup. Visi, misi dan tujuan ini juga sudah terinternalisasi (tahu dan paham) oleh semua warga sekolah. Kebijakan di sekolah yang berbasis lingkungan dapat dilihat dari visi, misi dan tujuan serta kurikulum yang diterapkan di sekolah. Visi SMP Negeri 2 Dayun adalah "Menumbuhkan sikap memelihara dan mencegah pencemaran lingkungan .Menciptakan generasi yang peduli lingkungan sehingga dapat mencegah kerusakan lingkungan. Membudayakan hidup bersih, sehat, cinta lingkungan sekolah dan masyarakat". Selanjutnya tujuan sekolah yang berkaitan dengan lingkungan terdapat pada poin keempat yaitu "Menumbuhkan rasa cinta dan peduli lingkungan baik lingkungan sekolah maupun masyarakat",

Pertama adalah pelaksanaan kebijakan sekolah Adiwiyata 
menghendaki visi, misi dan tujuan serta kurikulum sekolah yang berbasis kebijakan sekolah Adiwiyata. Keempat hal tersebut merupakan landasan sekolah dalam menjalankan kegiatan di sekolah. Setiap kebijakan yang diambil sekolah harus memperhatikan aspek lingkungan. Selain itu sekolah juga wajib memfasilitasi pembelajaran ataupun sarana dan prasarana dalam menunjang pendidikan lingkungan seperti yang tercantum dalam visi, misi, tujuan dan kurikulum yang telah dirumuskan dan ditetapkan di sekolah. Visi, misi dan tujuan ini juga sudah terinternalisasi (tahu dan paham) oleh semua warga sekolah. Visi, misi dan tujuan sekolah selalu di sosialisasikan kepada warga sekolah, tujuannya agar warga sekolah lebih mengetahui dan memahami akan tujuan dari visi, misi dan tujuan sekolah tersebut.

Adapun pelaksanaan kebijakan sekolah Adiwiyata SMP Negeri 2 Dayun Kabupaten Siak adalah sebagai berikut, peraturan yang melandasi kebijakan sekolah peduli dan berbudaya lingkungan meliputi Memorandum Bersama Mendiknas No 0142/U/1996 dan No. Kep 89/MenLH/5/1996, Kesepakatan Bersama dengan Depdiknas KEP 7/MenLH/06/2005 dan No. 05/VI/KB/2005, UU No 20 Tahun 2003, UU RI No. 32 Tahun 2009 pada tingkat nasional kebijakan sekolah peduli dan berbudaya lingkungan. Tentang penetapan nama sekolah imbas yang mendapat pembinaan oleh sekolah Kebijakan dan Pengembangan Pendidikan Volume 2, Nomor 1, Januari 2014; 82-88 ISSN: 2337-7623; EISSN: 2337-7615 85 Adiwiyata tingkat nasional.

Kedua adalah Pelaksanaan Kurikulum berbasis sekolah Adiwiyata. Pelaksanaan kurikulum berbasis sekolah adiwiyata di SMP Negeri 2 Dayun kabupaten Siak diantaranya ialah: 1) pembelajaran Mulok Lingkungan Hidup seperti budi daya tanaman organik, pembibitan tanaman, pembenihan ikan, pemanfaatan limbah untuk handy craft dan composting. 2) Integrasi Pendidikan Lingkungan Hidup pada mata pelajaran yang relevan, yaitu dengan mengembangkan issu lokal dan issu global misalnya: global warming, pencemaran air, udara, tanah, kebakaran hutan, banjir, pengenalan energi alternatif dan terbarukan, pelestarian badak bercula satu di kawasan Taman Nasional Ujung Kulon, dan lain sebagainya. 3) Mengekpos berbagai karya inovasi lingkungan hidup, pada berbagai media misalnya melalui majalah dinding, pameran, website, media massa, makalah, kliping dan lain sebagainya.

Peraturan mengenai integarsi pendidikan lingkungan hidup dalam proses belajar mengajar di sekolah telah tertuang pada SK Kepala Sekolah Nomor 800/117-SMP.04/2013. Kegiatan pembelajaran merupakan salah satu cara memberikan pengetahuan tentang lingkungan kepada siswa. Hal ini penting untuk membentuk karakter peduli lingkungan.

Ketiga dalah kegiatan berbasis partisipatif. Kegiatan berbasis partisipatif yang dilakukan oleh warga sekolah di SMP Negeri 2 Dayun diantarnya ialah: 1) Kegiatan perawatan/pemeliharaan sarana prasarana sekolah oleh warga sekolah misalnya dengan adanya piket kelas, kegiatan operasi bersih, pemilahan sampah dan lain sebagainya. 2) Pemanfaatan lahan sekolah untuk Pembelajaran Lingkungan Hidup, misalnya inventarisasi tanaman, pemberian nama latin, pembibitan, budi daya tanaman, hutan sekolah, pengecekan kandungan zat pewarna dan bahan berbahaya pada jajanan kantin 
dan lain sebagainya. 3) Mengembangkan kegiatan ekstrakurikuler berbasis lingkungan misalnya melalui kegiatan PMR/UKS, Pramuka, Olah Raga Prestasi, Majalah Dinding, Paskibra, Seni Teater, Kompos dan lain sebagainya. 4) Mengikuti dan melaksanakan berbagai kegiatan aksi lingkungan dan peringatan hari-hari lingkungan hidup melalui berbagai kegiatan, misalnya: kampanye penggunaan moda transportasi ramah lingkungan, lomba melukis, lomba foto, lomba mading, lomba puisi, lomba kebersihan, lomba karya tulis, penanaman pohon, penanaman benih ikan, aksi bersih lingkungan, sosialisasi, lomba poster tema lingkungan, pameran hasil daur ulang sampah dan lain sebagainya.

Keempat adalah pengelolaan sarana pendukung ramah lingkungan. Pengelolaan sarana pendukung ramah lingkungan yang dilakukan oleh warga sekolah di SMP Negeri 2 Dayun diantarnya ialah: 1) Penyediaan sarana prasarana untuk mengatasi permasalahan lingkungan hidup di sekolah, misalnya tong sampah, TPS, sumur resapan, ruang terbuka hijau, hutan sekolah, rumah kompos, biopori dan lain sebagainya. 2) Penyediaan sarana prasarana untuk mendukung pembelajaran Lingkungan Hidup di sekolah, misalnya laboratorium IPA, peralatan keterampilan, alat biopori, peralatan UKS dan lain sebagainya. 3) Terpeliharanya sarana prasarana sekolah yang ramah lingkungan, misalnya: pemeliharaan taman, gedung, hutan sekolah, tanaman hias dan lain sebagainya. 4) Peningkatan pengelolaan dan pemeliharaan fasilitas sanitasi sekolah, misalnya pemeliharaan drainase, pembersihan kamar mandi/WC, pengelolaan sampah dan lain sebagainya. 5) Pemanfaatan listrik, air dan alat tulis kantor secara efisien, misalnya penghematan listrik, kertas, dan alat-alat tulis lainnya. 6) Peningkatan kualitas pelayanan kantin sehat dan ramah lingkungan, misalnya penyediaan kantin yang refresentatif, pengontrolan jajanan siswa, pengetesan kandungan bahan pengawet dan zat berbahaya pada makanan, penyuluhan dan pembinaan petugas kantin dan lain sebagainya.

Penggelolaan sarana prasarana atau fasilitas pendidikan harus selalu dijalankan oleh pihak sekolah dengan dukungan dari semua warga sekolah, orang tua peserta didik dan semua pemangku kebijakan. Hal ini sangat penting mengingat kesadaran masyarakat terhadap pemeliharaan dan pelestarian lingkungan hidup masih rendah, sebagai buktinya yaitu kerusakan lingkungan baik itu pencemaran, kerusakan hutan, berkurangnya berbagai species hewan, berkurangnya kesuburan dan produktivitas tanah, dan lain-lain semakin bertambah dari tahun ketahun. Sekolah sebagai lembaga yang akan mencetak generasi penerus bangsa dan pewaris dunia di kemudian hari mempunyai peran strategis untuk melahirkan generasi yang mampu mewariskan bumi kita kepada generasi mendatang agar dapat menopang kehidupannya.

Dari pembahasan peneliti diatas dapat disimpulkan bahwa pelaksanaan kebijakan sekolah Adiwiyata di SMP Negeri 2 Dayun Kabupaten Siak Kabupaten Siak sudah berjalan dengan baik hal ini tampak dari kegiatan yang dilakukan mulai dari kepala sekolah SMP Negeri 2 Dayun sampai siswa SMP Negeri 2 Dayun dalam melaksanakan semua peratuaran yang telah ditetapkan disekolah sesuai dengan langkah-langkah dan tujuan yang titetapkan. 


\section{Keberhasilan Pendidikan Karakter Melalui Kebijakan Sekolah Adiwiyata}

Pendidikan karakter adalah pendidikan yang menanamkan dan mengembangkan karakter-karakter luhur kepada anak, sehingga mereka memiliki kepribadian, akhlak mulia, dan budi pekerti sehingga karakter terbentuk dan menjadi ciri khas pada anak. Untuk mencapai keberhasilan pendidikan karakter melalui kebijakan sekolah adiwiyata adalah Pendidikan berkarakter peduli lingkungan dapat dipahami sebagai usaha yang dilakukan untuk meningkatkan kepedulian terhadap lingkungan, baik itu dalam melestarikan, menjaga ataupun mencegahnya dari kerusakan lingkungan yang akan terjadi dengan merujuk dari indikator peduli lingkungan di SMP Negeri 2 Dayun kabupaten Siak. Indikator pendidikan karakter SMP Negeri 2 Dayun meliputi menerapkan nilai-nilai kebersamaan dalam kehidupan masyarakat, bangsa, dan bernegara demi terwujudnya persatuan dalam Negara Kesatuan Republik Indonesia. Menghargai karya seni dan budaya nasional, Menghargai tugas pekerjaan dan memiliki kemampuan untuk berkarya, Menerapkan hidup bersih, sehat, bugar, aman, dan manfaatkan waktu luang dengan baik pembiasaan memelihara lingkungan SMP, Indikator kelas berupa memelihara dan membersihkan lingkungan kelas, tersedianya tempat sampah di depan kelas, memasang stiker atau tulisan perintah menjaga kebersihan kelas.

Keberhasilan pendidikan karakter melalui kebijakan sekolah Adiwiyata yang dimiliki SMP Negeri 2 Dayun Kabupaten Siak adalah petugas piket membersihkan ruangan sebelum KBM dimulai dan dan setelah jam pelajaran usai, guru tidak merokok di lingkungan sekolah terutama saat mengajar di dalam kelas, guru menyisipkan materi PLH pada saat KBM, melaksanakan Sabtu bersih dengan pembagian kapling yang telah disediakan oleh tim Ospasling (Polisi Lingkungan), perawatan tanaman yang berada di Green House mulai dari pembibitan, penanaman, pemupukan, pengenalan hama, sampai pada penyiraman dan pengenalan karakter tanaman, mengikuti even yang bertema green, pemanfaatan kertas bekas untuk berbagai jenis kerajinan tangan, pemanfaatan botol aqua bekas, yang menunjukkan adanya dampak positif dari pengelolaan kebijakan sekolah Adiwiyata.

Pembiasaan-pembiasaan terus diterapkan di seluruh komponen sekolah sehingga menjadi peka terhadap lingkungan yang selalu membiasakan hidup bersih dan cinta lingkungan menjadi kebiasaan warga sekolah SMP Negeri 2 Dayun kabupaten Siak, tidak saja dilingkungan sekolah akan tetapi juga dilingkungannya masing-masing.

Dari hasil wawancara dan observasi dapat disimpulkan bahwa keberhasilan pendidikan karakter melalui kebijakan sekolah Adiwiyata di SMP Negeri 2 Dayun adalah melalui Menerapkan hidup bersih, sehat, bugar, aman, dan manfaatkan waktu luang dengan baik, Merawat diri dan lingkungan sekolah dan keberhasilan tersebut dibuktikan dengan adanya pengharaan prediket sekolah Adiwiyata tingkat Kabupaten dengan Surat Keputusan Bupati Siak No. 253 / HK / KPTS / 2014 tentang nama-nama sekolah Adiwiyata berprestari tingkat SD, SMP, SMA/SMK pada tahun 2014. Kemudian secara berturut-turut pada tahun 2015 SMP Negeri 2 Dayun mendapat penghargaan Sekolah Adiwiyata Propinsi Riau dengan piagam penghargan yang diberikan oleh 
Guburnur Riau pada bulan Agustus 2015 dan pada tahun itu juga berhasil menyandang Sekolah Adiwiyata Tingkat Nasional dengan Surat Keputusan Menteri Lingkungan Hidup Dan Kehutanan Repulik Indonesia No. 610/MENLHK-BP2SDM/2015 tentang penerimaan penghargaan Sekolah Adiwiyata Nasional tahun 2015 dengan piagam penghargaan diberikan langsung oleh Menteri Lingkungan Hidup.

\section{SIMPULAN}

1. Kebijakan Sekolah Adiwiyata Sebagai Penerapan Pendidikan Karakter Di SMP Negeri 2 Dayun Kabupaten Siak sesungguhnya dapat berjalan dengan baik sesuai tujuan karena dilakukan melalui tahap-tahap pengembangan pendidikan karakter yang telah dicanangkan kementerian pendidikan nasional (2010), yaitu melalui tahap pengetahuan, tahap pelaksanaan, dan tahap habituasi (pembiasaan). Dalam hal ini sekolah telah melakukan penyempurnaan visi misi sekolah berbudaya lingkungan, mengintegrasikan pendidikan lingkungan hidup dengan pembelajaran dikelas, dan membentuk program kerja berbasis partisipatif sehingga menjadi kebiasaan bagi peserta didik.

2. Nilai-nilai karakter yang dikembangkan oleh SMP Negeri 2 Dayun melalui kebijakan sekolah Adiwiyata pada dasarnya merupakan keberhasilan dari tahap-tahap pengembangan pendidikan karakter yang dilakukan oleh sekolah, yaitu melalui tahap pengetahuan (knowing), pelaksanaan (acting), dan kebiasaan (habit). Dalam hal ini sekolah melakukan tahap pelaksanaan dengan memberdayakan program Adiwiyata sebagai basis dalam membentuk nilai karakter yang kemudian dilakukan sekolah secara konsisten dan berkesinambungan sehingga dapat melatih peserta didik untuk terbiasa dalam melakukan perbuatan moral (moral acting).

Sekolah perlu menerapkan manajemen pengetahuan sebagai pelengkap dan pengintegrasian dari manajemen berbasis sekolah yang sekarang ini masih terpisah-pisah dalam masing-masing manajemen komponen sekolah, karena melalui manajemen pengetahuan akan tercipta organisasi pembelajar yang memungkinkan setiap individu yang ada menjadi berkembang sehingga dapat membelajarkan murid secara optimal dan akhirnya mutu sekolah dan lulusannya dapat meningkat.

\section{DAFTAR PUSTAKA}

Aminullah, Erman. (2004) Berpikir Sistematik Untuk Pembuatan Kebijakan Publik, bisnis dan ekonomi, PPM. Jakarta

Adisusilo, Sutarjo. 2013. Pembelajaran Nilai Karakter. Jakarta: PT Raja Grafindo Persada.

Albertus, Doni Koesoema. 2012. Pendidikan Karakter Utuh dan Menyeluruh. Yogyakarta: Kanisius

Chaerul Hasyim. 2009. Program Adiwiyata: Sekolah Peduli dan Berbudaya Lingkungan.ndppm.uii.ac.id/dokume $\mathrm{n} / \mathrm{sem} \quad$ inar/UIIECO_SPIRITUAL-KLH.pdf diakses 12 November 2017

Darma, Kesuma Dkk. 2011. Pendidikan Karakter Kajian Teori dan Praktik di Sekolah. Bandung: PT Remaja Rosdakarya. 
Hasbullah, M. 2015. Kebijakan Pendidikan: Dalam Perspektif Teori, Aplikasi, dan Kondisi Objektif Pendidikan di Indonesia. Jakarta: Rajawali Pers.

Sumarno. 2012. Manajemen Pengetahuan Untuk Meningkatkan Mutu Sekolah. jurnal Pendidikan Ekonomi. Vol 4, No 02 (2012)

Kemen LH. 2012. Keputusan Menteri Lingkungan Hidup Nomor : KEP51/MENLH/10/1995

tentang Baku Mutu Limbah Cair Bagi Kegiatan Industri. Jakarta : Kementerian Lingkungan Hidup Republik Indonesia

E. Mulyasa. 2005. Menjadi Guru Profesional. Bandung: PT. Remaja Rosda Karya

Nugroho, Riant. 2008. Public Policy. PT Elex Media Komputindo: Jakarta.

Siswanto, H.B. 2005. Pengantar Manajemen. Jakarta: PT. Bumi Aksara.

Suyanto. (2009). Urgensi Pendidikan Karakter. Direktorat Jendral Pendidikan Dasar Kementrian Pendidikan Nasional. ttp://konselingindonesia.com/ind ex.php?option=com_content\&ta sk=view $\&$ id $=307 \&$ Itemid $=102$. (Diakses tanggal 24 Oktober 2017).

Thoha, Miftah.2010. Kepemimpinan Dalam Manajemen. Jakarta: PT. Raja Grafindo Persada.

Pariang, N.F.E.. 2013.Peran dan Kesiapan Apoteker Dalam Menyongsong Diberlakukannya
Jaminan Kesehatan Nasional Tahun 2014. Ikatan Apoteker Indonesia. Palangka Raya: IAI

Yahya, Khan. 2010. Pendidikan Karakter Berbasis Potensi Diri. Yogyakarta: Pelangi Publishing 